\title{
STUDY ON THE IN-PLANE SHEAR PERFORMANCE OF SPACER FABRICS IN COMPOSITE FORMING
}

\author{
ŠTUDIJ STRIŽNIH LASTNOSTI KOMPOZITNO OBLIKOVANIH \\ TKANIN S SENDVIČ STRUKTURO
}

\author{
Veerakumar Arumugam ${ }^{1}$, Rajesh Mishra ${ }^{1}$, Maros Tunak ${ }^{2}$, Blanka Tomkova ${ }^{1}$, Jiri Militky ${ }^{1}$ \\ ${ }^{1}$ Technical University of Liberec, Faculty of Textile, Department of Materials Engineering, 46117 Liberec, Czech Republic \\ ${ }^{2}$ Technical University of Liberec, Faculty of Textile, Department of Textile Evaluation, 46117 Liberec, Czech Republic \\ veerakumar27@gmail.com
}

Prejem rokopisa - received: 2017-07-11; sprejem za objavo - accepted for publication: 2017-09-21

doi:10.17222/mit.2017.115

\begin{abstract}
Shear properties are important not only for standard fabrics but for textile-reinforced composites as well. Shear is one of the most common flaws that occurs during textile-composite-reinforcement forming processes. To ensure the production of high-quality textile-fabric-reinforced composites when forming complex shapes, the potential for an in-plane deformation of the fabric reinforcement must be taken into consideration. This research paper will present the emerging textile fabric of this decade, commonly known as the 3D spacer fabric, which could be used as the reinforcement for complex-shaped composites. The objective of this research was to study the shear behavior of 3D knitted spacer fabrics using a picture-frame fixture. The images acquired during the loading process were used for an analysis in order to obtain a full-field displacement and shear angles at the chosen points on the surface of a test specimen. To determine its suitability for measuring the in-plane shear properties of the 3D knitted spacer fabrics, experimental and analytical investigations of the picture-frame shear fixture were conducted. The non-linear behavior of the shear force versus the shear angle and deformation mechanism were analyzed. Load-displacement curves of intra-ply shear tests were also analyzed. In addition, a MATLAB program was developed, using the Hough transform to analyze the shear angle in the real-time image taken during the displacement of the specimen at various positions. The image-analysis results were compared with the actual experimental results. These findings are important requirements when using 3-dimensional textile fabrics as the reinforcement in a composite formation.
\end{abstract}

Keywords: 3D spacer fabrics, shear deformation, shear stress, image analysis

Strižne lastnosti niso pomembne le za standardne tkanine temveč tudi za ojačane tekstilne kompozite. Prestrig je ena od najbolj pogostih napak, ki nastopi med procesom ojačitve tekstilnega kompozita. Da bi zagotovili proizvodnjo visokokvalitetnega tekstila iz ojačanih kompozitnih tkanin, je potrebno med oblikovanjem kompleksnih oblik upoštevati deformacije ojačitve zaradi ravninskega striga. V tem članku avtorji opisujejo raziskave novih tekstilnih tkanin, ki se v zadnjem času imenujejo 3D-prostorske tkanine in bi lahko bile uporabne za ojačanje kompleksno oblikovanih kompozitov. Predmet te študije je strižno obnašanje prostorsko pletene tkanine z uporabo PFF-tehnologije (angl.: Picture Frame Fixture). Zato, da bi dobili odmike po celotnem polju in strižne kote $\mathrm{v}$ izbrani točki na površini testnega vzorca, so avtorji prispevka slike, zajete med procesom nalaganja, uporabili za analizo. Izvedli so praktične in analitične preiskave, da bi določili primernost merjenja v ravnini striga pletenih 3D-prostorskih tkanin. Analizirali so nelinearno obnašanje strižnih sil v odvisnosti od strižnega kota in mehanizem deformacije. Prav tako so analizirali krivulje odvisnosti obremenitev-odmik, dobljene med strižnimi preizkusi. Razvili so program na osnovi MATLAB, z uporabo Houghove transformacije, da bi analizirali strižni kot v realnem času odjema slike med odmikom vzorca $\mathrm{v}$ različnih položajih. Rezultate analize slike so primerjali z dejanskimi eksperimentalnimi rezultati. Ugotovitve avtorjev so pomembne za oblikovanje zahtev, potrebnih za uporabo 3D-tekstilnih tkanin, za ojačanje v kompozitnih tvorbah.

Ključne besede: 3D prostorske tkanine, strižna deformacija, strižne napetosti, analiza slike

\section{INTRODUCTION}

The shearing behavior of a fabric determines its performance properties when subjected to a wide variety of complex deformations in use. This property enables the fabric to undergo complex deformations and to conform to the shape of the body. Shear properties are important not only for fabrics but for textile composites as well. Automated manufacturing of textile, composite shell-like products typically requires draping of dry or pre-impregnated textile sheets. Large local deformations occur in a textile sheet in order for it to adapt to the curved shape. These deformations affect the local fibre directions, volume fractions, and thickness, i.e., the factors that, together with the consolidation level and the occurrence of flaws (e.g., wrinkling and tearing), determine the product quality. ${ }^{1}$ Three-dimensional (3D) textile structural composites provide excellent through-thickness strength, outstanding damage tolerance and favorable impact and fatigue resistance. ${ }^{2}$ As one type of the $3 \mathrm{D}$ textile structural reinforcements for composites, the 3D spacer fabric has been widely used in the engineering field owing to its easy and efficient processing in warp and weft knitting. In addition, the most attractive advantage of the spacer fabric is the three-dimensional shape-forming capacity to manufacture composites. 3D-spacer-fabric preforms have excellent mechanical properties and good formability. ${ }^{3}$ With the development of the preforming technology, complex shapes and different sizes of the structural parts can be produced. In the structural 
integrated manufacture of composite products, the 3D spacer fabric is preformed according to the shape of the final composite product that can be complex. ${ }^{4}$

The in-plane behavior and the interlaminar behavior of 3D spacer fabrics are the most important deformations, and the shear behavior predominates the deformation mode of a material. ${ }^{5}$ It is valuable to study the inter/intra-ply shear behavior of 3D fabrics because of their wide application in the production, especially in the case of a forming process. Lin et al. established a finiteelement model based on the geometry of a 2D fabric to simulate an in-plane shear deformation, and the simulation results were identical with the experiments. Chen et al. developed a FEM model to predict in-plane and interlaminar shear properties of laminates. ${ }^{6}$ However, the in-plane shear behavior of a spacer fabric has been rarely reported. A. Charmetant et al. ${ }^{7}$ built a hyper-elastic model to simulate the formability of a 3D fabric.

In this paper, a picture-frame shear fixture is presented and a careful study of its performance and the in-plane-shear behaviors of 3D warp-knitted spacer fabrics with different densities, thicknesses and structures is reported on. The shear stresses versus shear-angle curves and the wrinkle position of the in-plane shear test are recorded and load-displacement curves of the in-plane shear test are also analyzed. In addition, a program was developed in MATLAB using the Hough transform to analyze the shear angle in the image. These image-analysis results are compared with the actual experimental results. Overall, it is expected that a clear picture of tailoring a knitted spacer fabric with a promising shear property is created for composite-forming applications.

\section{EXPERIMENTAL PART}

Six different spacer fabrics made of a polyester filament yarn were knitted, using a Raschel warp-knitting machine with a gauge of E22 and 6 guide bars. The sample classification is clearly presented in Table $\mathbf{1}$. The structure and knit pattern of both the lock knit and hexagonal net-warp-knit structures are given in Figure 1. The fabric characteristics such as areal density, stitch

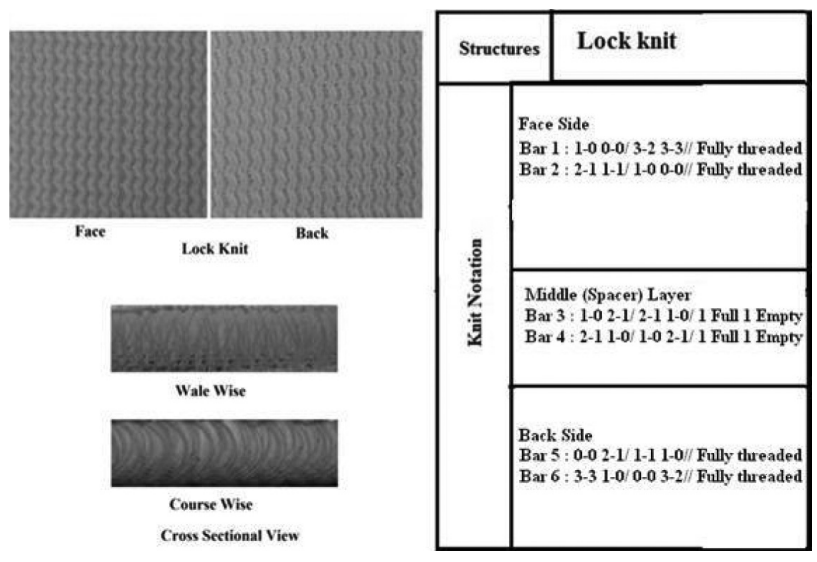

Figure 1: Structure and knit pattern of warp-knitted spacer fabrics density, structure and thickness, are presented in Table 2. All the experiments were carried out under the standard ambient condition and as per standard.

Table 1: Description of warp-knitted spacer fabrics

\begin{tabular}{|c|c|c|c|c|c|c|}
\hline S. No. & $\begin{array}{l}\text { Struc- } \\
\text { ture }\end{array}$ & $\begin{array}{c}\text { Fibre } \\
\text { composi- } \\
\text { tion }(\%)\end{array}$ & $\begin{array}{l}\text { Face } \\
\text { layer } \\
\text { (dtex) }\end{array}$ & $\begin{array}{c}\text { Middle } \\
\text { layer } \\
\text { (spacer) } \\
\text { (dtex) }\end{array}$ & $\begin{array}{l}\text { Back } \\
\text { layer } \\
(\text { dtex })\end{array}$ & $\begin{array}{l}\text { Spacer- } \\
\text { yarn } \\
\text { dia. } \\
(\mathrm{mm}) \\
\end{array}$ \\
\hline WAS 1 & $\begin{array}{c}\text { Lock } \\
\text { knit }\end{array}$ & $\begin{array}{c}100 \% \\
\text { Polyester }\end{array}$ & $83 f 36$ & $33 f 1$ & $83 f 36$ & 0.055 \\
\hline WAS 2 & $\begin{array}{c}\text { Lock } \\
\text { knit }\end{array}$ & $\begin{array}{c}100 \% \\
\text { Polyester }\end{array}$ & $83 f 36$ & $33 \mathrm{f} 1$ & $83 f 36$ & 0.055 \\
\hline WAS 3 & $\begin{array}{c}\text { Lock } \\
\text { knit }\end{array}$ & $\begin{array}{c}100 \% \\
\text { Polyester }\end{array}$ & $83 f 36$ & $33 \mathrm{f} 1$ & $83 \mathrm{f} 36$ & 0.055 \\
\hline WAS 4 & $\begin{array}{c}\text { Lock } \\
\text { knit }\end{array}$ & $\begin{array}{c}100 \% \\
\text { Polyester }\end{array}$ & $83 \mathrm{f} 36$ & $108 \mathrm{f} 1$ & $83 f 36$ & 0.1 \\
\hline WAS 5 & $\begin{array}{c}\text { Lock } \\
\text { knit }\end{array}$ & $\begin{array}{c}100 \% \\
\text { Polyester }\end{array}$ & $83 f 36$ & 108f1 & $83 f 36$ & 0.1 \\
\hline WAS 6 & $\begin{array}{c}\text { Lock } \\
\text { knit }\end{array}$ & $\begin{array}{c}100 \% \\
\text { Polyester }\end{array}$ & $83 \mathrm{f} 36$ & 108f1 & $83 f 36$ & 0.1 \\
\hline
\end{tabular}

\section{In-plane shear behavior - a picture-frame test}

A picture-frame test, as shown in Figure 2, is an effective way of characterizing the in-plane shear property of fabrics. The picture-frame test is preferred by many researchers for shear testing since it generates a pure state of the strain that can be imposed on the test specimen. Shearing is induced by restraining the textile reinforcement in a rhomboid deformation frame with the fibers constrained to move parallel to the frame edges. The frame is extended at diagonally opposing corners using simple tensile-testing equipment. The $3 \mathrm{D}$ spacer
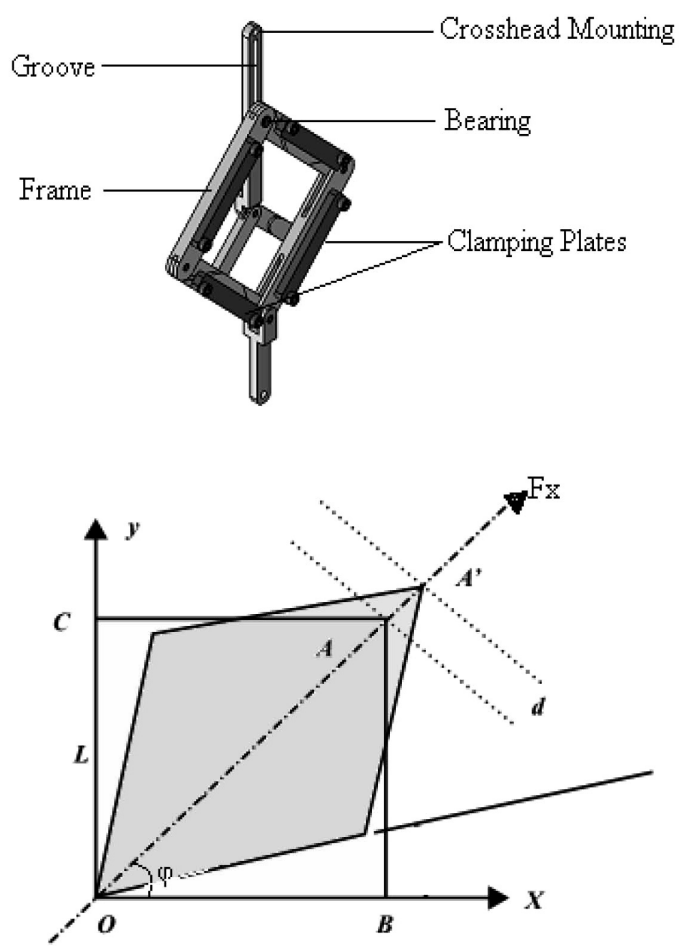

Figure 2: Picture-frame shear fixture and deformation kinematics 
Table 2: Structural characteristics of warp-knitted spacer fabrics

\begin{tabular}{|c|c|c|c|c|c|c|c|c|c|c|c|c|c|}
\hline \multirow{2}{*}{$\begin{array}{l}\text { Warp-spacer } \\
\text { samples }\end{array}$} & \multicolumn{4}{|c|}{ Stitch density (stitches/cm²) } & \multicolumn{4}{|c|}{$\begin{array}{c}\text { GSM } \\
\left(\mathrm{g} \mathrm{m}^{-2}\right)\end{array}$} & \multicolumn{4}{|c|}{ Thickness (mm) } & \multirow{2}{*}{$\left.\begin{array}{c}\text { Density } \\
\left(\mathrm{kg} \mathrm{m}^{-3}\right)\end{array}\right)$} \\
\hline & Mean & ME & LL & UL & Mean & ME & LL & UL & Mean & $\mathrm{ME}$ & LL & UL & \\
\hline WAS 1 & 120.4 & 1.1 & 119.30 & 121.50 & 87.33 & 0.72 & 261.62 & 263.06 & 1.50 & 0.03 & 1.47 & 1.53 & 174.89 \\
\hline WAS 2 & 121 & 1.4 & 119.60 & 122.40 & 89.73 & 0.77 & 353.55 & 355.09 & 2.50 & 0.04 & 2.46 & 2.54 & 141.73 \\
\hline WAS 3 & 120.3 & 1.3 & 119.00 & 121.60 & 90.77 & 3.10 & 442.88 & 449.08 & 3.50 & 0.03 & 3.47 & 3.53 & 127.42 \\
\hline WAS 4 & 119 & 1.2 & 117.80 & 120.20 & 72.31 & 0.68 & 572.41 & 573.77 & 1.50 & 0.02 & 1.48 & 1.52 & 382.06 \\
\hline WAS 5 & 120 & 1.1 & 118.90 & 121.10 & 74.73 & 0.62 & 871.30 & 872.54 & 2.50 & 0.01 & 2.49 & 2.51 & 348.77 \\
\hline WAS 6 & 120.5 & 0.9 & 119.60 & 121.40 & 75.69 & 0.69 & 1173.4 & 1174.8 & 3.50 & 0.01 & 3.49 & 3.51 & 335.47 \\
\hline
\end{tabular}

$\mathrm{ME}$ - margin of errors, LL - lower limit, UL - upper limit

fabrics for the shear tests were prepared according to the size of the picture frame and deformation kinematics is shown in Figure 2. The complete displacement of the specimens during the loading process was recorded using image-analysis methods. The images were captured at certain regular intervals using a digital camera (Figure 3). A special program was developed in MATLAB 7.10 (R 2010a) using the Hough transform to find the angle between the lines on the specimens.

A direct measurement of the axial load and shear angle is possible with the equations below. The shear force $\left(F_{\mathrm{s}}\right)$ is determined by the axial force $\left(F_{\mathrm{x}}\right)$, frame-rig length $(L)$ and frame angle $(\varphi)$. Meanwhile, the frame angle can be determined directly from the crosshead displacement $(d)$. The shear angle $(\gamma)$ can be obtained from the frame angle using Equations (2) and (3):

$$
\begin{gathered}
F_{\mathrm{s}}=\frac{F_{x}}{2 \cos \varphi} \\
\varphi=\cos ^{-1}\left[\frac{L \sqrt{2}+d}{2 L}\right] \\
\gamma=\frac{\pi}{2}-2 \varphi
\end{gathered}
$$

\section{RESULTS AND DISCUSSIONS}

\subsection{Influence of structural characteristics on the in-plane shear behavior}

In Figure 4, the stress-strain curve reveals that the shear resistance decreases with an increase in the thickness. It can be seen that the samples have similar behaviors as they behave linearly in the surface-extension stage due to the same surface structure and density. In the next stage of the shear deformation, the compressive stress also plays a vital role, making the fabrics resist the shear force. It is also observed that the thicker fabric has the ability to undergo a larger deformation in both shear and compression conditions. The shear stress-strain behavior of spacer fabrics appears to change significantly with an appreciable decrease in the spacer thickness.

It is observed that the shear stress is high for the fabrics with a coarser spacer yarn. During the surface elongation and compression (the $1^{\text {st }}$ stage), a higher shear

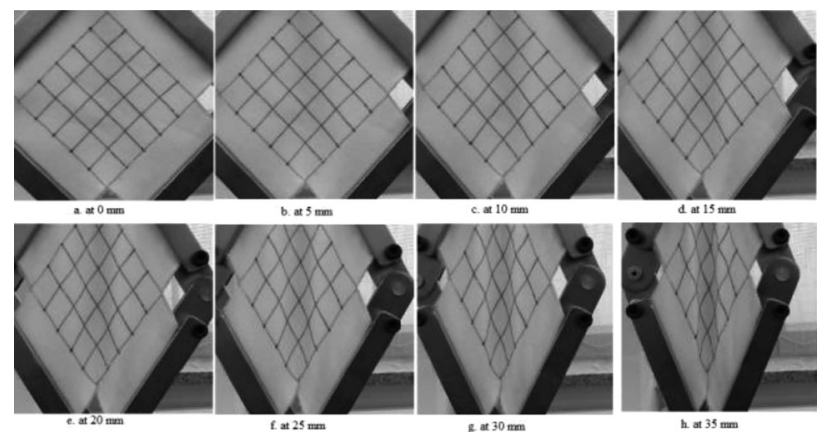

Figure 3: In-plane shear angles of spacer fabrics using image-analysis method

force is observed for the fabrics with a coarser spacer yarn as compared to the fabrics made of finer spacer yarns. It might be that due to the large diameter and linear density, the coarse spacer yarns have the ability to resist more compressive stress than the fabrics made of a finer spacer yarn. In the $2^{\text {nd }}$ stage, pre-buckling is observed after $20 \%$ of the shear strain because the surface layers come in contact with each other, leading to a locking effect. The fabrics have almost identical stress-strain curves, with the same thickness of the lock-knit spacers in the $1^{\text {st }}$ stage region. However, a significant difference in the shear stress-strain behavior is observed in the densification stage. This is due to the fact that the

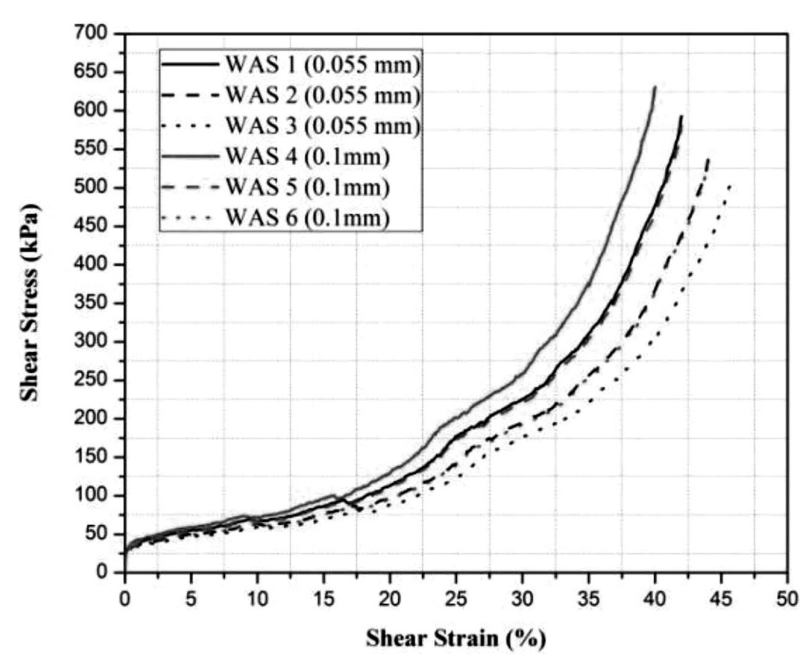

Figure 4: Influence of structural characteristics on the in-plane shear behavior 
internal surface and spacer layer experience a closer compaction, which depends on the thickness, the surface structure and spacer-yarn properties.

\subsection{Determination of the shear angle of warp-knit spacers using the image-analysis method}

The spacer-fabric samples (WAS 1-WAS 6) exhibit smooth and linear increases in the shear angle until a 25-mm displacement. The irregular trend in the shear angle observed after the $25-\mathrm{mm}$ displacement may be due to the fact that the spacer fabric undergoes a compaction, which leads to buckling. In a buckled fabric, it is extremely complicated to find the same shear angle at different points, using the Hough-transformation imageanalysis method. The image-analysis shear angle is plotted against the shear strain for the lock-knit structures such as the lock knit (WAS 1-WAS 6) as given in Figure 5. Also, a linear model fit was presented in the figures with the shear strain as an independent variable and the shear angle as a dependent variable. The regression equation for all the samples is given in Table $\mathbf{3}$, with the correlation coefficient $\left(R^{2}\right)$ to find the degree of linear fit.

Table 3: Prediction of the shear angle using image analysis as a function of the shear strain

\begin{tabular}{|c|c|c|c|c|c|c|}
\hline Equation & \multicolumn{6}{|c|}{$y=a+b * x$} \\
\hline DF & \multicolumn{6}{|c|}{ Model -1 , Error -7, Total -8} \\
\hline \multicolumn{2}{|c|}{ Sample Nos. } & Value & $\begin{array}{c}\text { Standard } \\
\text { error }\end{array}$ & $\begin{array}{l}\text { Residual } \\
\text { sum of } \\
\text { squares }\end{array}$ & F value & Prob $>F$ \\
\hline \multirow{2}{*}{ WAS 1} & Intercept & -2.091 & 1.668 & \multirow{2}{*}{51.552} & \multirow{2}{*}{245.259} & \multirow{2}{*}{0.000} \\
\hline & Slope & 1.097 & 0.070 & & & \\
\hline \multirow{2}{*}{ WAS 2} & Intercept & -1.347 & 1.474 & \multirow{2}{*}{40.269} & \multirow{2}{*}{280.577} & \multirow{2}{*}{0.000} \\
\hline & Slope & 1.037 & 0.062 & & & \\
\hline \multirow{2}{*}{ WAS 3} & Intercept & -0.071 & 1.097 & \multirow{2}{*}{22.283} & \multirow{2}{*}{414.594} & \multirow{2}{*}{0.000} \\
\hline & Slope & 0.938 & 0.046 & & & \\
\hline \multirow{2}{*}{ WAS 4} & Intercept & -2.736 & 2.229 & \multirow{2}{*}{92.088} & \multirow{2}{*}{144.907} & \multirow{2}{*}{0.000} \\
\hline & Slope & 1.127 & 0.094 & & & \\
\hline \multirow{2}{*}{ WAS 5} & Intercept & -2.884 & 1.859 & \multirow{2}{*}{64.069} & \multirow{2}{*}{218.124} & \multirow{2}{*}{0.000} \\
\hline & Slope & 1.154 & 0.078 & & & \\
\hline \multirow{2}{*}{ WAS 6} & Intercept & -2.516 & 1.561 & \multirow{2}{*}{45.129} & \multirow{2}{*}{300.433} & \multirow{2}{*}{0.000} \\
\hline & Slope & 1.136 & 0.066 & & & \\
\hline
\end{tabular}

\section{CONCLUSIONS}

The in-plane shear behavior of spacer fabrics is greatly influenced by their surface structures, type of the spacer yarn and the fabric stitch density. The outer-layer structure affects the monofilament-yarn inclination, binding condition with the surface, distribution and multifilament stitches in the surface layers. The non-linearity of the shear deformation increases after the limiting locking angle, which initiates the buckling of a sample. Significant differences between the shear stress-strain curves for the samples were obtained in the densification stage. They were due to the fact that the internal surface and spacer layer experience a closer

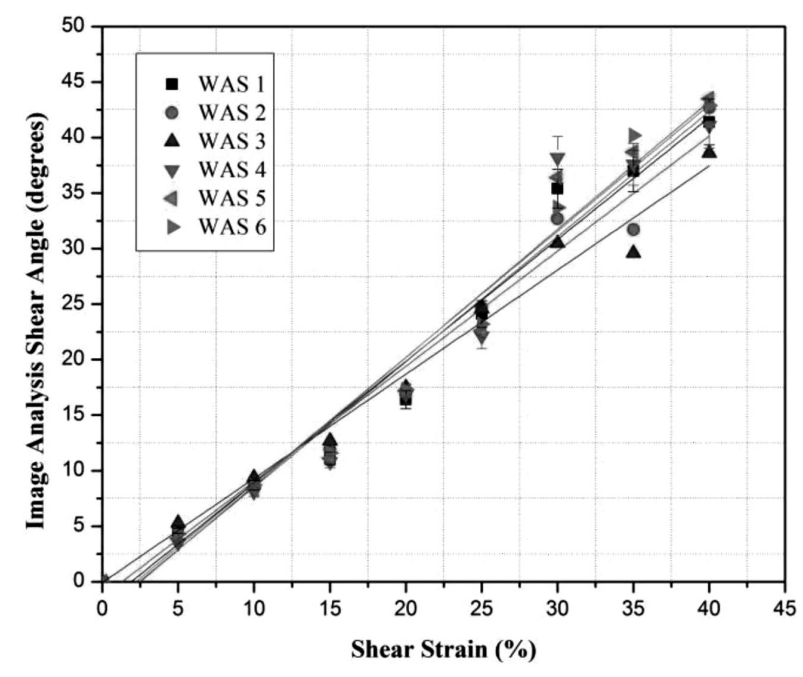

Figure 5: Determination of the shear angle of warp-knit spacers using image-analysis method

compaction, which depends on the thickness, surface structure and spacer-yarn properties. The differences between the image analysis and the calculated shear angle, using the sample length at the chosen points, are relatively small. There is no significant difference until pre-buckling occurs, but a significant difference occurs after a 20-mm displacement.

\section{Acknowledgment}

This work was supported by the Department of Materials Engineering, Faculty of Textile, Technical University of Liberec, Czech Republic and project No. 21195 within the student-grant scheme, Czech Republic.

\section{REFERENCES}

${ }^{1}$ V. Arumugam, R. Mishra, J. Militky, M. Tunak, In-plane shear behavior of 3D knitted spacer fabrics, J. Ind. Text., 46 (2016), 868, doi:10.1177/1528083715601509

${ }^{2}$ V. Arumugam, R. Mishra, J. Militky, J. Salcova, Investigation on Thermo-Physiological and Compression Characteristics of Weft Knitted Spacer Fabrics, J. Text. Inst., 108 (2017), 1095, doi:10.1080/ 00405000.2016.1220035

${ }^{3}$ V. Arumugam, R. Mishra, J. Militky, M. Tunak, D. Kremenakova, M. Venkatraman, Investigation on Intra-Ply Shear Properties of 3D Weft Knitted Spacer Fabrics by Image Analysis, JFBI, 2 (2016), 63, doi:10.3993/jfbim0023

${ }^{4}$ B. El Abed, S. Msahli, Numerical simulation of woven fabric wrinkling, J. Text. Inst., 102 (2011), 77, doi:10.1080/00405000903509686

${ }^{5}$ J. Cao, R. Akkerman, P. Boisse, J. Chen, Characterization of mechanical behavior of woven fabrics: Experimental methods and benchmark results, Compos. Part A: Appl. S., 39 (2008), 1037, doi:10.1016/j.compositesa.2008.02.016

${ }^{6}$ Q. Q. Chen, P. Boisse, C. H. Park, A. Saouab, J. Bréard, Intra/interply shear behaviors of continuous fiber reinforced thermoplastic composites in thermoforming processes, Compos. Struct., 93 (2011), 1692, doi:10.1016/j.compstruct.2011.01.002

${ }^{7}$ A. Charmetant, J. G. Orliac, E. Vidal-Sallé, P. Boisse, Hyperelastic model for large deformation analyses of 3D interlock composite preforms, Compos. Sci. Technol., 72 (2012), 1352, doi:10.1016/ j.compscitech.2012.05.006 